\title{
CORRECTION
}

\section{Correction: Whither Digital Archaeological Knowledge? The Challenge of Unstable Futures}

\author{
Jeremy Huggett*, Paul Reilly ${ }^{\dagger}$ and Gary Lock ${ }^{\ddagger}$
}

This article details a correction to the article: Huggett, J., Reilly, P. and Lock, G., 2018. Whither Digital Archaeological Knowledge? The Challenge of Unstable Futures. Journal of Computer Applications in Archaeology, 1(1), pp. 42-54. DOI: https://doi.org/10.5334/jcaa.7.

Keywords: scenario analysis; walled gardens; knowledge brokering; knowledge maps; archaeological knowledge

\section{Correction}

The article "Whither Digital Archaeological Knowledge? The Challenge of Unstable Futures' (Huggett, Reilly and Lock 2018) contains the following spelling error:

Agiatis Benardou's name is misspelt as "Bernardou". As a result there are two incorrect references, which should be Benardou et al (2017) and Lock et al (2016).

\section{Competing Interests}

The authors have no competing interests to declare.

\section{References}

Benardou, A, Champion, E, Dallas, C and Hughes, L. 2017. Introduction: a critique of digital practices and research infrastructures. In: Benardou,
A, Champion, E, Dallas, C and Hughes, L (eds.), Cultural Heritage Infrastructures in the Digital Humanities, 1-14. Abingdon: Routledge. DOI: https://doi.org/10.4324/9781315575278-1

Huggett, J, Reilly, P and Lock, G. 2018. Whither Digital Archaeological Knowledge? The Challenge of Unstable Futures. Journal of Computer Applications in Archaeology, 1(1): 42-54. DOI: https://doi. org/10.5334/jcaa.7

Lock, G, Benardou, A, Dallas, C, Reilly, P and Huggett, J. 2016. Unstable futures/Potential pasts: scenarios for digital computing 2020. Round Table session, CAA, Oslo. https://ocs.caaconference.org/ index.php? conference $=$ caa\&schedConf $=$ caa201 $6 \&$ page $=$ paper $\&$ op $=$ view $\&$ path $\% 5 B \% 5 D=1767$ [Last accessed 29 October 2017].

\footnotetext{
* University of Glasgow, GB

+ University of Southampton, GB

* University of Oxford, GB 
How to cite this article: Huggett, J, Reilly, P and Lock, G. 2019. Correction: Whither Digital Archaeological Knowledge?

The Challenge of Unstable Futures. Journal of Computer Applications in Archaeology, 2(1), pp. 1-2. DOl: https://doi.org/10.5334/ jcaa.21

Submitted: 23 November 2018 Accepted: 23 November $2018 \quad$ Published: 14 January 2019

Copyright: ( 2019 The Author(s). This is an open-access article distributed under the terms of the Creative Commons Attribution 4.0 International License (CC-BY 4.0), which permits unrestricted use, distribution, and reproduction in any medium, provided the original author and source are credited. See http://creativecommons.org/licenses/by/4.0/.

]u[ Journal of Computer Applications in Archaeology, is a peer-reviewed open access journal 